\title{
Current status of subclinical form of babesiosis and anaplasmosis in cattle at Rangpur district in Bangladesh
}

\author{
ASMS Rahman ${ }^{1,3}$, SMMR Sumon ${ }^{1}$, MAHNA Khan ${ }^{2}$ and MT Islam ${ }^{1 *}$ \\ ${ }^{1}$ Department of Medicine, ${ }^{2}$ Department of Pathology, Faculty of Veterinary Science, Bangladesh Agricultural \\ University, Mymensingh 2202, Bangladesh; ${ }^{3}$ Department of Livestock Services, Farmgate, Dhaka, Bangladesh
}

\begin{abstract}
Babesiosis and anaplasmosis are important tick borne diseases and they are responsible for significant economic losses for livestock industry worldwide. A cross-sectional survey was conducted in randomly selected 400 cattle at two upazilas of Rangpur district in Bangladesh, to estimate the prevalence and identify the risk factors of Babesia and Anaplasma infections. Microscopic examination of Giemsa's stained blood films was carried out for the tentative diagnosis of infections. Multiplex PCR was also performed to confirm microscopically positive samples. To identify the risk factors, odds ratio and $95 \%$ confidence interval were calculated. The overall prevalence of Babesia and Anaplasma infections were 1.5\% and 3.5\%, respectively. The prevalence of Babesia infections recorded in Gangachara and Pirgachaupazilas were 1.3\% and 1.7\%, respectively while it was 3.8\% and 3.3\%, respectively for Anaplasma infection. Insignificantly higher prevalence of both infections was recorded in crossbred cattle than those of indigenous cattle. Female cattle had insignificantly higher infection (3.8\%) with Anaplasma than the male cattle (2.3\%) while no infection with Babesia was found in any male cattle. None of the calves $€ 1 \mathrm{yr}$ ) had infection with either organism. However, infection with both organisms was more prevalent in young cattle ( $>1-2.5 \mathrm{yr})$ than those of adult cattle ( $>2.5 \mathrm{yr})$. The availability of blood sucking ticks was one of the potential risk factors for both infections ( $\mathrm{OR}=6-7)$. Age ( $>1-2.5 \mathrm{yr})$ was identified as another important risk factor which had significant association with the occurrence of Anaplasma infection $(\mathrm{OR}=4.36)$. The information generated from this study could be useful as basic information for further advanced epidemiological study and formulation of control measures of the tick borne diseases.
\end{abstract}

Key words: Babesiosis, Anaplasmosis, Prevalence, Risk factors, Multiplex PCR.

Progressive Agriculturists. All rights reserve

*Corresponding Author: taohid@bau.edu.bd

\section{Introduction}

Babesiosis and anaplasmosis are important tick borne diseases (TBDs) of farm animals. Babesiosis is a haemoprotozoan and anaplasmosis is a haemobacterial infection of cattle (Dumler et al., 2001). Both diseases have a serious economic impact due to obvious reason of morbidity and mortality, decreased production and lowered working efficiency, and have been reported in Bangladesh (Chowdhury et al., 2006; Karim et al., 2012; Siddiki et al., 2010; Talukdar and Karim, 2001). The agroecological and geo-climatic conditions of Bangladesh are highly favorable for growth and multiplication of ticks which act as natural vectors of babesiosis and anaplasmosis. Though several species of Babesia and Anaplasma are involved in the occurrence of babesiosis and anaplasmosis, commonly bovine babesiosis is caused by the hemoprotozoa Babesia bovis and Babesia bigemina, and anaplasmosis is caused by the Anaplasma marginale and Anaplasma central (Dumler et al., 2001; Lucimar et al., 2014). The most important biological vector for these four agents is the tick Rhipicephalus (Boophilus) 
microplus, which is distributed in tropical and subtropical regions (Estrada-Pena et al., 2006). In addition to the biological transmission by ticks, $A$. marginale can be transmitted mechanically by blood sucking flies or iatrogenically by fomites contaminated with blood from infected cattle (Dreher et al., 2005; Kocan et al., 2010). The pathogens that cause TBDs are often found together within a single host (Georges et al., 2001; Simuunza et al., 2011). The dynamics of infection of these parasites are dependent on factors such as vector population, transmission capability of the vector, and host susceptibility (Kocan et al., 2010). Babesiosis and anaplasmosis are widely distributed throughout the world, particularly in tropical and subtropical countries including India, Pakistan and Bangladesh (Ghosh et al., 2007).

Banerjee et al. (1983) recorded $14.53 \%$ overall prevalence of subclinical babesiosis through a serological survey in three dairy farms in Mymensingh and Dhaka districts of Bangladesh. Chowdhury et al. (2006) recorded much higher prevalence $(70 \%)$ of anaplasmosis in clinically suspected cattle of Sirajganj district than those of other inland reports. Talukdar and Karim (2001) reported that 33\% cattle of Baghabari Milk Shed Area had Anaplasma infection. Siddiki et al. (2010) recorded lower prevalence (1\%) of haemoprotozoan diseases in Red Chittagong Cattle in some areas of Chittagong district. A wide range of mortality (6 to $33 \%$ ) associated with clinical signs of these diseases have also been reported in cattle of Bangladesh (Karim, 2013; Samad, 1988). However, it is necessary to have the epidemiological data of a region in order to formulate and implement preventive measures. Recently, practicing veterinarians of different upazilas of Rangpur district had noticed that occurrences of babesiosis and anaplasmosis are increasing. But the epidemiological data on these diseases in Rangpur district is not known. The topography of Rangpur district is diversified by plane and riverine areas. Besides, Rangpur is one of the most important routes of cattle smuggling from India. In addition, the climatic condition and geographical location of the areas might favor the growth and multiplication of different vectors. Therefore, the present study was undertaken to estimate the prevalence and identify the potential risk factors associated with babesiosis and anaplasmosis in cattle.

\section{Materials and Methods}

\section{Study areas and duration}

A multistage random sampling method was applied according to Thrusfield (2005). Among eight upazilas (Sadar, Mithapukur, Badarganj, Pirgacha, Pirganj, Taraganj, Gangachara and Kaunia) of Rangpur district two upazilas namely Gangachara and Pirgacha were selected randomly. Gangachara located $12 \mathrm{~km}$ north-west and Pirgacha located 20 km south-east from Rangpur district headquarter. Two unions from Gangachara and three from Pirgacha were randomly selected. From each union, two villages were randomly selected to have a total of 10 villages. One hundred and sixty households were randomly selected from 10 villages to have 400 cattle older than 7 months and of either sex. The study was conducted over a period of 9 months, from January to September 2014.

\section{Sample size}

A cross-sectional survey was conducted in 400 cattle of 2 upazilas of Rangpur district, namely Gangachara and Pirgacha. The minimum sample size $(n=384)$ was calculated using the formula, $n=Z^{2} P(1-P) / d^{2}$, considering the average expected prevalence of $50 \%$, absolute desired precision of $5 \%$ and confidence level of 95\% (Thrusfield, 2005). Therefore, finally the survey was conducted with 400 cattleheads.

\section{Data collection}

Animal and herd level data along with other relevant information were collected using a pre-tested questionnaire through face to face interview of the farmers. Selected animals were categorized into three age groups: calves $\leqslant 1$ year), young ( $>1-2.5$ years), and adult ( $>2.5$ years).

\section{Collection and microscopic examination of blood samples}

Blood samples were collected from 400 cattle by puncturing ear vein of each cattle using sterile disposable syringe and butterfly needle. Three thin blood smears prepared from each sample before 
adding EDTA were fixed with absolute methanol and subsequently stained with Giemsa's stain and finally examined under microscope (100X). EDTA added to the remaining blood samples and shifted to the laboratory in ice box within the shortest possible time. The blood samples were preserved at $-20^{\circ} \mathrm{C}$ for DNA extraction and PCR assay.

\section{Extraction of DNA}

DNA extraction was done only from Giemsa positive samples. Genomic DNA Purification kit (WizardGenomic DNA Purification kit Promega Corporation, 2800 Woods Hollow Road, Madision
U.S.A) was used to extract DNA from blood using manufacturer instructions.

\section{Polymerase Chain Reaction (PCR)}

Multiplex PCR was carried out in a final reaction volume of $50 \mu \mathrm{l}$ in thin walled PCR tubes to amplify genomic DNA of B. bovis, A. marginale organisms. The TNC PCR Master Mix Kit (Promega, USA) was used for this purpose. Oligonucleotide primers used for PCR amplification of selective genomic DNA of $B$. bovis and A. marginale organisms are listed herewith (Table 1). The final reactions volume were

Table 1. Oligonucleotide primers used for PCR amplification of selective genomic DNA of $B$. bovis and $A$. marginale organisms

\begin{tabular}{|c|c|c|c|}
\hline $\begin{array}{c}\text { Primers } \\
\text { name }\end{array}$ & Sequence & $\begin{array}{l}\text { Target genes and } \\
\text { amplicon size }\end{array}$ & Reference \\
\hline \multirow{2}{*}{$\begin{array}{l}\text { A. } \\
\text { marginale }\end{array}$} & F (5'-GCT CTA GCA GGT TAT GCG TC-3’) & \multirow{2}{*}{$\begin{array}{l}\text { Major surface protein-1b } \\
\text { gene- } 265 \text { bp }\end{array}$} & \multirow{4}{*}{$\begin{array}{l}\text { Bilgic et al. } \\
\quad \text { (2013) }\end{array}$} \\
\hline & R (5'-CTG CTT GGG AGA ATG CAC CT-3') & & \\
\hline \multirow{2}{*}{ B. bovis } & F (5'-CAA GCA TAC AAC CAG GTG G -3’) & \multirow{2}{*}{$\begin{array}{l}\text { Multi-copy VESA- 1a } \\
\text { gene- } 166 \text { bp }\end{array}$} & \\
\hline & R (5'-ACC CCA GGC ACA TCC AGC TA-3') & & \\
\hline
\end{tabular}

prepared (50 $\mu \mathrm{l})$ containing $2 \mathrm{X}$ PCR master mix 25 $\mu \mathrm{l}$, forward primer for $B$. bovis $1 \mu \mathrm{l}$ (20 pmol), forward primer $A$. marginale $1 \mu \mathrm{l}(20 \mathrm{pmol})$, reverse primer $B$. bovis $1 \mu \mathrm{l}$ (20 pmol), reverse primer $A$. marginale $1 \mu \mathrm{l}(20$ pmol), extracted DNA $5 \mu \mathrm{l}$ (200$300 \mathrm{gg}$ ) and nuclease free $\mathrm{H}_{2} \mathrm{O} \quad 16 \mu \mathrm{l}$. The amplification protocol was as follows: initial denaturation at $95{ }^{\circ} \mathrm{C}$ for $5 \mathrm{~min}$, followed by 40 cycles of $94{ }^{\circ} \mathrm{C}$ for $1 \mathrm{~min}$, annealing at $52{ }^{\circ} \mathrm{C}$ for 1 min, elongation at $65{ }^{\circ} \mathrm{C}$ for $1 \mathrm{~min}$, with a final step at $65{ }^{\circ} \mathrm{C}$ for $10 \mathrm{~min}$. The amplification products were separated on $1.5 \%$ agarose gel stained with ethidium bromide and photographed.

\section{Data analysis}

Data were entered into Epi Info V. 3.5.3 (CDC, Atlanta) and checked carefully for any missing or inconsistent data. Prevalence and odds ratio were calculated by using the "Table" function in the software.

\section{Results}

\section{Microscopic and PCR findings}

Following Giemsa's staining blood samples of 400 cattle were examined microscopically and 6 cattle found positive for Babesia organism and 14 found positive for Anaplasma organism. Of the positive cases, 2 were found positive for both Babesia and Anaplasma organisms. On microscopic examination, Babesia organisms were found as paired parasites at an acute angle to each other (Figure 1), and Anaplasma sp. appeared as dense, homogeneously stained blue-purple inclusions located toward the margin of the infected erythrocyte (Figures 1-2). From the microscopic findings, it may be assumed that the organisms were $B$. bigemina and $A$. marginale. Microscopically positive samples either for Babesia or Anaplasma organisms were subjected to multiplex PCR with primers specific for $B$. bovis and $A$. marginale. No samples generated an amplicon of $166 \mathrm{bp}$, expected size of targeted area from Multi- 


\section{Babesiosis and anaplasmosis in cattle}

copy VESA-1a gene-166 bp of $B$. bovis, which indicated that Babesia organisms found in microscopic examination were not Babesia bovis suggesting that they were $B$. bigemina. However, 14 samples positive for Anaplasma organisms on

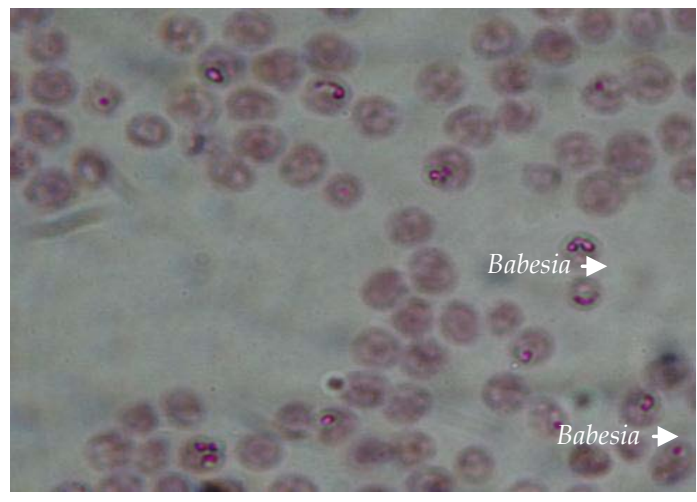

microscopic examination generated an amplicon of 265 bp in mPCR (Figure 3), expected size of targeted area from Major surface protein-1b gene-265 bp of $A$. marginale suggests that the organisms were $A$. marginale.

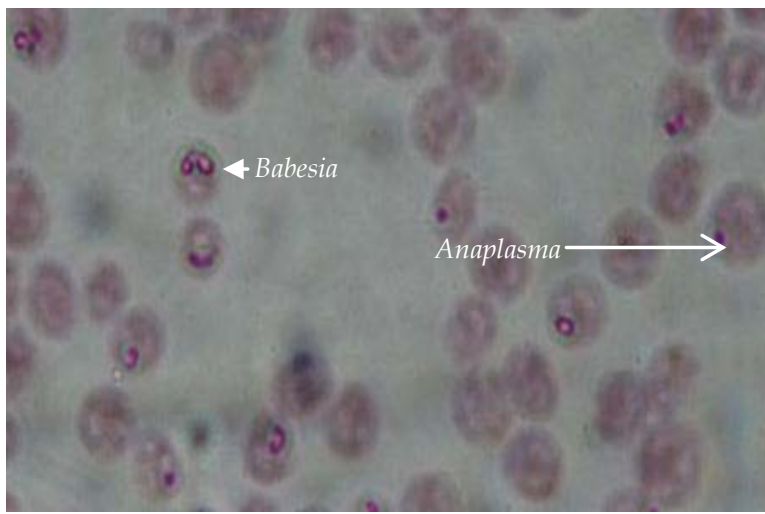

Figure 1. Pear shaped Babesia organism (arrow head) and pink color dot Anaplasma organism were seen in the margin (arrow) of RBC in Giemsa stained blood smears made from cattle (100x).
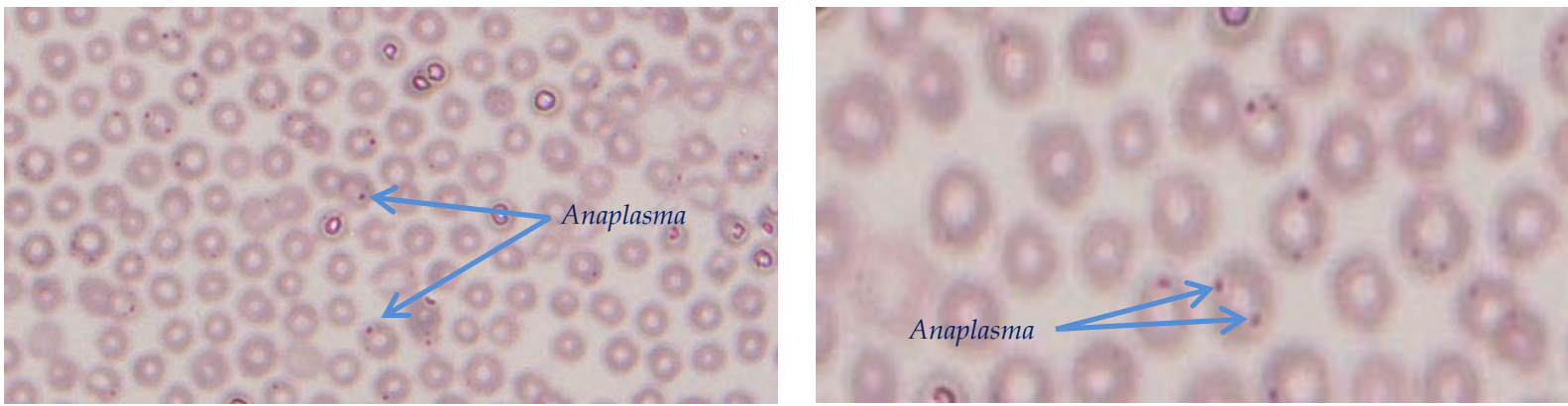

Figure 2. Pink color dot Anaplasma organisms (arrow) were seen in the margin of RBC in Giemsa stained blood smears made from cattle (100x).

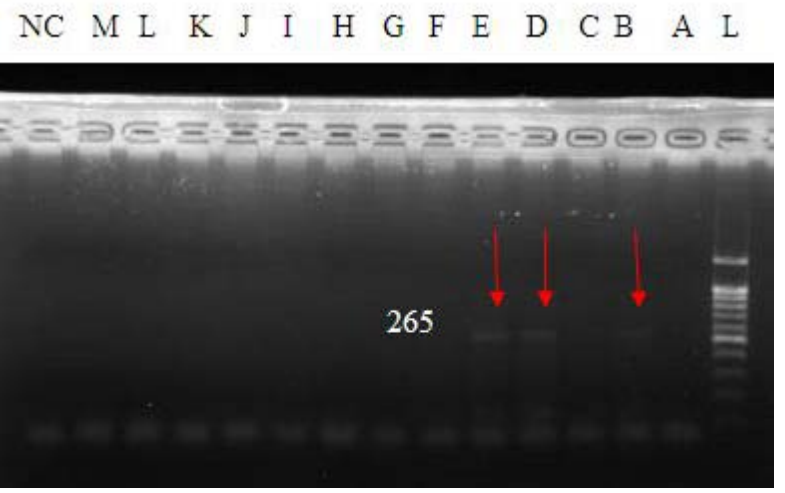

Figure 3. Amplification of the genomic DNA of B. bovis and A. marginale from blood of cattle. Lane L is for 100 bp ladder; NC is for negative control; Lanes A-M, Samples; Lanes B, D, E having amplicons of 265 bp indicated presence of $A$. marginale organisms. 


\section{Prevalence of babesiosis and anaplasmosis in cattle}

As PCR was carried out with primers targeted for only Babesia bovis and Anaplasma marginale, the microscopic results were considered for the diagnosis of Babesia and Anaplasma infections. The overall prevalence of Babesia and Anaplasma infection were 1.5\% and 3.5\%respectively (Table 2-3). All the cattle except one positive either for Babesia or for Anaplasma had high fever $\left(>104^{\circ} \mathrm{F}\right)$ without any other clinical signs. However, of all the positive cases, no rise in rectal temperature was observed in one cattle which had mixed infection with Babesia and Anaplasma.

The prevalence of Babesia infection was almost similar in cattle of Gangachara and Pirgachaupazilas, $1.3 \%$ and $1.7 \%$, respectively (Table 2). And the prevalence of Anaplasma infection was comparatively higher than Babesia infection in these two upazilas, 3.8\% and 3.3\%, respectively (Table 3). Though the prevalence of Babesia and Anaplasma infections was higher in crossbred cattle than those of local indigenous cattle but no significant difference was noted (Table 2-3).

Female cattle had insignificantly $(P=0.381)$ higher infection rate (3.8\%) with Anaplasma than the male cattle (2.3\%) while infection with Babesia was not seen in any of male cattle. Age-wise analysis revealed that none of the calves $(\leqslant 1 \mathrm{yr})$ had infection with either organism. However, infection with both organisms was more prevalent in young cattle $(>1$ $2.5 \mathrm{yr})$ than those of adult cattle $(>2.5 \mathrm{yr})$. The prevalence of Anaplasma infection was $3.8 \%$ and $2.3 \%$ in young and adult cattle, respectively (Table 3) while it was $2.2 \%$ and $1.4 \%$ in case of Babesia infection (Table 2).

\section{Risk factors of babesiosis and anaplasmosis in cattle}

Availability of blood sucking ticks was one of the potential risk factors for both Babesia and Anaplasma infections. Around 27\% (109/400) cattle were exposed to blood sucking ticks and, of them $3.7 \%$ and $9.2 \%$ had infection with Babesia and Anaplasma infections, respectively. In case of Babesia infection, the odds of cattle exposed to blood sucking ticks was about 6 times higher than those of unexposed to blood sucking ticks (95\% CI $=0.99$ 30.49; $P=0.049$ ), while it was about 7 times in case of Anaplasma infection (95\% CI $=2.22-23.63, P<$ 0.001). Age (>1-2.5 yr) was another important risk factor which had significant association with the occurrence of Anaplasma infection (OR = 4.36, 95\% $\mathrm{CI}=1.47-12.92, P=0.008)$.

\section{Discussion}

The present study provides basic information on the prevalence and associated risk factors of babesiosis and anaplasmosis in cattle of two representative upazilas of Rangpur district. The overall prevalence of Anaplasma infection (3.5\%) was comparatively higher than Babesia infection (1.5\%). Availability of blood sucking ticks was one of the potential risk factors for both Babesia and Anaplasma infections. Age (>1-2.5 yr) was identified as another important risk factor which had significant association with the occurrence of Anaplasma infection. On PCR assay, $B$. bovis was not detected in samples that were microscopically positive for Babesia organisms. Therefore, it may be assumed that microscopically positive Babesia organisms were $B$. bigemina. The existence of $B$. bigemina has also been reported earlier (Banerjee et al., 1983; Samad et al., 1989). All the 14 samples positive for Anaplasma organisms on microscopic examination generated an amplicon of 265 bp following PCR assay with A. marginalespecific primers, which suggests that Anaplasma organsims detected here in this study were $A$. marginale. The overall prevalence of Babesia infection recorded in this study was $1.5 \%$, which fully supports the earlier report of Siddiki et al. (2010)who recorded 1\%, and partially supports the reports of Shahidullah (1983), Samad et al. (1989) and Chowdhury et al. (2006) who recorded 2.29\%, $3.28 \%$ and $3.3 \%$ prevalence of Babesia bigemina infection in cattle, respectively based on microscopic examination of peripheral blood smears. A recent study of Karim et al. (2012) also recorded Babesia and Anaplasma organism through Giemsa's staining of blood smear. However, the findings are discordant with the findings of Banerjee et al. (1983) who reported higher prevalence (14.53\%) of subclinical 
babesiosis in dairy cattle of Mymensingh and Dhaka districts of Bangladesh. This might be due to the serological test (CA) the authors applied which might detect low level of infection in carrier animals.

Table 2. Prevalence and risk factors of Babesia infection in cattle population of Rangpur district

\begin{tabular}{|c|c|c|c|c|}
\hline Variables & $\begin{array}{c}\text { No. of cattle } \\
\text { examined }\end{array}$ & $\begin{array}{c}\text { Prevalence } \\
\text { No (\%) }\end{array}$ & $\begin{array}{l}\text { Odds ratio } \\
\text { (95\% CI) }\end{array}$ & $P$-value \\
\hline $\begin{array}{l}\text { Breed } \\
\text { Cross } \\
\text { Indigenous }\end{array}$ & $\begin{array}{c}307 \\
93\end{array}$ & $\begin{array}{l}5(1.6) \\
1(1.1)\end{array}$ & $\begin{array}{c}1.52(0.18-13.20) \\
\text { Reference }\end{array}$ & 0.575 \\
\hline $\begin{array}{l}\text { Age } \\
\text { Calf } \\
\text { Young } \\
\text { Adult }\end{array}$ & $\begin{array}{c}23 \\
93 \\
284\end{array}$ & $\begin{array}{l}0(0.0) \\
2(2.2) \\
4(1.4)\end{array}$ & $\begin{array}{c}\text { Not included } \\
1.54(0.28-8.54) \\
\text { Reference }\end{array}$ & 0.459 \\
\hline $\begin{array}{l}\text { Sex } \\
\text { Female } \\
\text { Male }\end{array}$ & $\begin{array}{c}313 \\
87\end{array}$ & $\begin{array}{l}6(1.9) \\
0(0.0)\end{array}$ & - & - \\
\hline $\begin{array}{l}\text { Availability } \\
\text { sucking tick } \\
\text { Yes } \\
\text { No }\end{array}$ & $\begin{array}{l}109 \\
291\end{array}$ & $\begin{array}{l}4(3.7) \\
2(0.7)\end{array}$ & $\begin{array}{c}5.50(0.99-30.49) \\
\text { Reference }\end{array}$ & 0.049 \\
\hline $\begin{array}{l}\text { Upazila } \\
\text { Gangachara } \\
\text { Pirgacha }\end{array}$ & $\begin{array}{l}160 \\
240\end{array}$ & $\begin{array}{l}2(1.3) \\
4(1.7)\end{array}$ & $\begin{array}{c}\text { Reference } \\
0.74(0.14-4.13)\end{array}$ & 0.544 \\
\hline Total & 400 & $6(1.5)$ & - & - \\
\hline
\end{tabular}

95\% CI= 95\% Confidence Interval.

Table 3. Prevalence and risk factors of Anaplasma infection in cattle population of Rangpur district

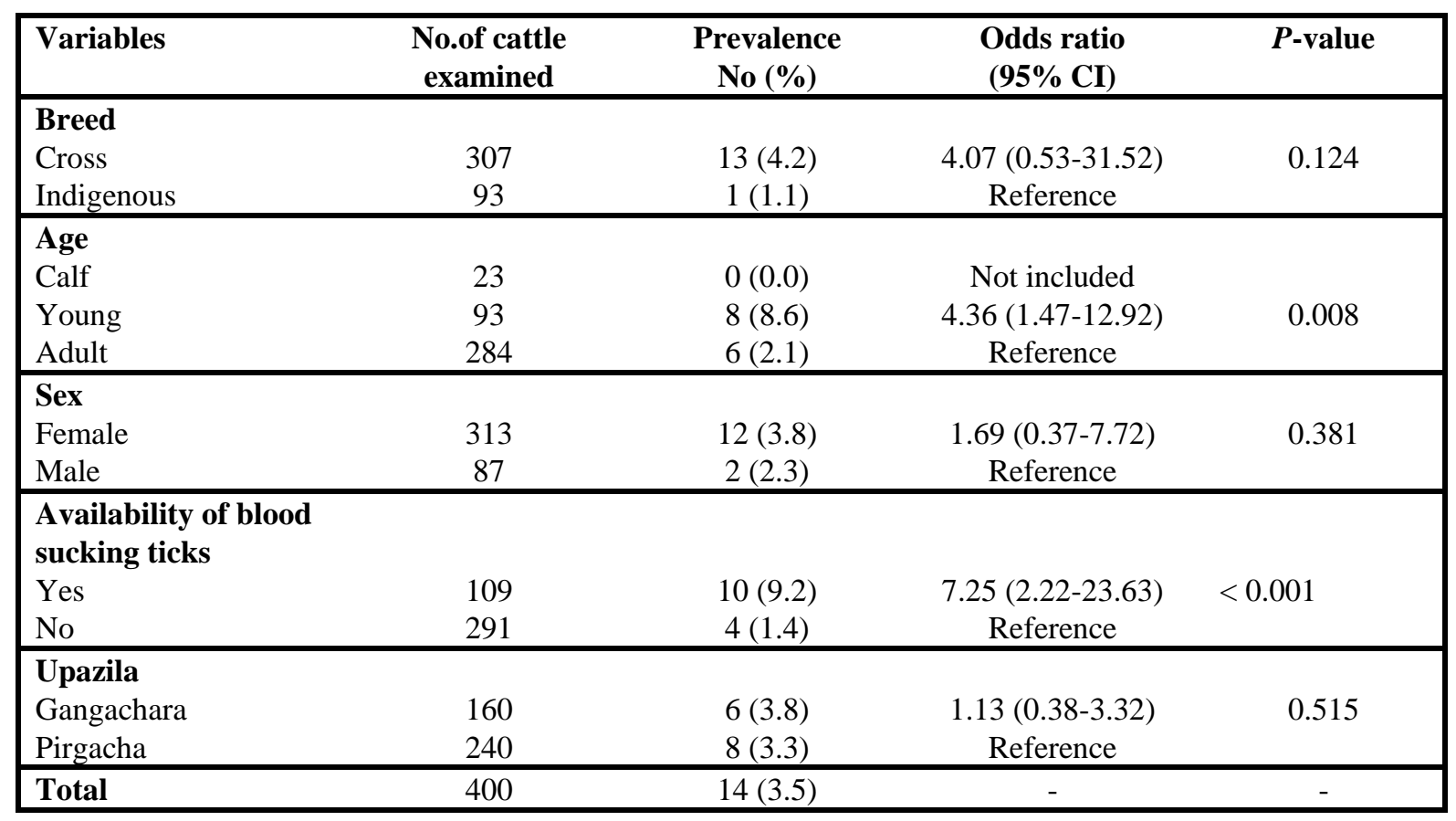

95\% CI= 95\% Confidence Interval. 
Anaplasma infection (3.5\%) recorded in this study is in agreement with the reports of Shahidullah (1983) and Samad et al. (1989) who recorded 3\% and 5.9\% Anaplasma infection in cattle. However, the present findings contradict with the findings of Chowdhury et al. (2006) who recorded extremely higher prevalence $(70 \%)$ of anaplasmosis than other inland reports. This difference might be due to the difference in study animals. The authors studied only clinically suspected cattle.

From this study it was revealed that crossbred cattle were affected more with anaplasmosis than indigenous cattle. Susceptibility of Anaplasma infection in crossbred cattle supports the earlier reports (Chowdhury et al., 2006; Sajid et al., 2014). Occurrence of Babesia infection was slightly higher in crossbred cattle than indigenous cattle. Earlier reports also found breed susceptibility of Babesia infection in cattle (Alim et al., 2012; Chowdhury et al., 2006; Samad, 2008). Constant exposure of infections and development of immunity against such infections might be responsible for lower prevalence in indigenous cattle (Siddiki et al., 2010). On the contrary, more attention in the management of crossbred cattle gives less chance of pre-exposure of vectors and develops no or less immunity, resulting frequent occurrence of such diseases (Ananda et al., 2009; Chowdhury et al., 2006; Siddiki et al., 2010).

Age also influences the occurrence of Babesia and Anaplasma infections. It was revealed that higher prevalence of Babesia infection found in young cattle than adult, which supports the report of Atif et al. (2012) who recorded the highest prevalence of babesiosis in cattle of 1 to 2 years old. Similarly, significantly higher prevalence was recorded in young cattle than adult. However, earlier reports suggested that there was wide variation in the occurrence of Babesia and Anaplasma infections in different age groups (Alim et al., 2012; Atif et al., 2012; Chowdhury et al., 2006; Sajid et al., 2014). Samad (2008) documented that young animals are less susceptible to babesiosis than cattle over 2 years of age and the infection is uncommon in animals over 5 years of age. Alim et al. (2012) and Ananda et al. (2009) also recorded that Babesia as well as
Anaplasma infections increased significantly ( $\mathrm{P}<$ $0.05)$ with the increase of age and the highest prevalence was recorded in adㅃtt 3(5 years) crossbred cattle. Kamani et al. (2010) also recorded higher prevalence of Babesia as well as Anaplasma infections in adult than young cattle. However, Chakraborti (2002) and Chowdhury et al. (2006) reported that greater infection rate was in animal in the 6-12 months age group. The authors also reported that infection is uncommon in animals over 5 years of age.

The prevalence of Babesia infection in the present study revealed that the occurrence of Babesia infection found only in female cattle. Susceptibility of anaplasmosis in relation to sex recorded in this study revealed that prevalence of Anaplasma infection was more prevalent in female cattle, which also conforms with the earlier reports (Alim et al., 2012; Atif et al., 2012; Chowdhury et al., 2006; Kamani et al., 2010; Sajid et al., 2014). The prevalence of Babesia and Anaplasma infection is higher in female cattle possibly due to the fact that they were kept longer for breeding and milk production purpose, supplied insufficient feed against their high demand (Kamani et al., 2010). Prevalence of Babesia as well as Anaplasma infections was significantly higher in tick infested cattle than the apparently tick free cattle. Tick infested cattle were about 6 times at greater risk of Babesia infection than the non-infested cattle. Similarly, tick-infested cattle found 7 times at greater risk of Anaplasma infection than tick free cattle. As blood sucking ticks are the vectors of both Babesia and Anaplasma organisms, the presence of them might influence the occurrence of infections with these organisms (Costa et al., 2013; Francisco de et al., 2013). However, the role of hematophagous flies may not be excluded in the occurrence of and Anaplasma infections (Costa et al., 2013; Francisco de et al., 2013) as in the present study hematophagous flies were found in 157 out of 160 households. A limitation of this study was the diagnosis of Babesia and Anaplasma infections based on findings of the microscopic examination of Giemsa's stained peripheral blood smears only 
though multiplex PCR was carried out with microscopically positive samples. In case of carrier state with low levels of parasitemia, Babesia and Anaplasma organisms may not be found on microscopic examination (Atif et al., 2012). However, for each sample three smears were examined very carefully so that not a single organism might escape.

\section{Conclusions}

The information generated from this study could be useful as basic information for further advance epidemiological study and formulation of control measures of the tick borne diseases. Further investigation using modern serological and molecular techniques with large number of samples for the identification of carriers, tick vectors and particularly hematophagic flies are needed.

\section{References}

Alim MA., Das S, Roy K, Masuduzzaman M, Sikder S, Hassan MM, Siddiki AZ, Hossain MA (2012). Prevalence of hemoprotozoan diseases in cattle population of Chittagong division, Bangladesh. Pak. Vet. J., 32:221-224.

Ananda KJ, Placid E, Puttalakshmamma GC (2009). Prevalence of hemoprotozoan diseases in crossbred cattle in Bangalore north.Vet. World, 12: $15-16$.

Atif FA, Khan MS, Iqbal JI, Arshad GM, Ashraf E, Ullah S (2012). Prevalence of Anaplasma marginale, Babesia bigemina and Theileria annulata infections among cattle in Sargodha District, Pakistan. Afr. J. Agric. Res., 7: 33023307.

Banerjee DP, Prasad KD, Samad MA (1983). Seroprevalence of Babesia bigemina infection in Cattle of India and Bangladesh. Indian J. Anim. Sci., 53:431-433.

Bilgic HB, Karagenc T, Simunza M, Shiels B, Tait A, Eren H, Weir W (2013). Development of a multiplex PCR assay for simultaneous detection of Theileria annulata, Babesia bovis and Anaplasma marginale in cattle. Exp. Parasitol.,133: 222-229.
Chowdhury S, Hossain MA, Barua SR, Islam S (2006). Occurrence of common blood parasites of cattle in Sirajgonj Sadar area of Bangladesh. Bangl. J. Vet. Med., 4: 143-145.

Costa VM, Ribeiro MF, Duarte AL, Mangueira JM, Pessoa AF, Azevedo SS, Barros AT, Riet-Correa F, Labruna MB (2013). Seroprevalence and risk factors for cattle anaplasmosis, babesiosis, and trypanosomiasis in a Brazilian semiarid region. Braz. J. Vet. Parasitol., 22: 207-213.

Dreher UM, Hofmann-Lehmann R, Meli ML, Regula G, Cagienard AY, Stark KDC, Doherr MG, Filli F, Hassig M, Braun U, Kocan KM, Lutz H (2005). Seroprevalence of anaplasmoses among cattle in Switzerland in 1998 and 2003: No evidence of an emerging disease. Vet. Microbiol., 107:71-79.

Dumler JS, Barbet AF, Bekker CP, Dasch GA, Palmer GH, Ray SC, Rikihisa Y, Rurangirwa FR (2001). Reorganization of genera in families Rickettsiaceae and Anaplasmataceae in the order Rickettsiales: unification of some species of Ehrlichia with Anaplasma, Cowdria with Ehrlichia and Ehrlichia with Neorickettsia, descriptions of six new species combinations and designation of Ehrlichia equi and 'HGE agent' as subjective synonyms of Ehrlichia phagocytophila. Int. J. Syst. Microbiol., 51: 2145-2165.

Estrada-Pena A, Bouattour A, Camicas JL, Guglielmone A, Horak I, Jongejan F, Latif A, Pegram R, Walker AR (2006). The known distribution and ecological preferences of the tick subgenus Boophilus (Acari: Ixodidae) in Africa and Latin America. Exp. Appl. Acarol., 38: 219-235.

Francisco de AL S, Juliana FVB, Lidiany VP, Ciro JSDC, Érica AC, Mucio FBR, Renato LS, Silvana MMSS (2013). Babesiosis and anaplasmosis in dairy cattle in Northeastern Brazil. Pesqu. Veter. Brasz., 33: 1057-1061.

Georges K, Loria GR, Riili S, Greco A, Caracappa S, Sparagano O (2001). Detection of hemoparasites in cattle by reverse line blot hybridization with a note on the distribution of ticks in Sicily. Vet. $P$ arasitol., 137: 231-241. 
Ghosh S, Azhahianambia P, Yadav BMP (2007). Upcoming and future strategies of tick control: a review. J. Vector Borne Dis., 44:79-89.

Kamani J, Sannusi A, Eqwu OK, Dogo GI, Tanko TJ, Kemza S, Takarki AE, Gbise DS (2010). Prevalence and significance of haemoparasitic infections of cattle in North-Central, Nigeria. Vet. World, 3: 445-448.

Karim MA (2013). Diagnosis of babesiosis, anaplasmosis and theileriosis in cattle using traditional methods and PCR. M. S. Thesis, Department of Pathology, Bangladesh Agricultural University, Mymensingh.

Karim MA, Rima UK, Hossain MZ, Habib MA, Isalm MS, Hossain MM, Khan MAHNA (2012). Adoption of Polymerase Chain Reaction techniques for the detection and differentiation of babesiosis, anaplasmosis and Theileriosis in clinically infected and slaughtered cattle. Bangl. Vet. J., 46: 31-43.

Kocan KM, De La Fuente J, Blouin EF, Coetzee JF, Ewing SA (2010). The natural history of Anaplasma marginale. Vet. Parasitol., 167: 95107.

Lucimar SA, Amauri AW, Fábio SC, Paulo LSC, George RA (2014). Bovine babesiosis and anaplasmosis complex: diagnosis and evaluation of the risk factors from Bahia, Brazil. Braz. J. Vet. Parasitol., 23: 328-336.

Sajid MS, Siddique RM, Khan SA, Iqbal Z, Khan $\mathrm{MN}$ (2014). Prevalence and Risk Factors of Anaplasmosis in Cattle and Buffalo Populations of District Khanewal, Punjab, Pakistan. Global Vet., 12: 146-153.

Samad MA (1988). Bovine Babesiosis in Bangladesh. 2. Clinical Prevalence. Livestock Adv.,13: 32-36.

Samad MA (2008). Babesiosis and Anaplasmosis. In:A Textbook of Animal husbandry and Veterinary Science (2nd ed.) Vol. 2. pp. 12621263.

Samad MA, Bashar SA, Shahidullah M, Ahmed MU (1989 Prevalence of haemoprotozoan parasites in cattle of Bangladesh. Indian J. Vet. Med., 13: 50-51.

Shahidullah (1983) Studies on haemoprotozoan disease of goats and cattle with their vector ticks. M. S. Thesis, Department of Medicine, Bangladesh Agricultural University, Mymensingh.

Siddiki AZ, Uddin MB, Hasan MB, Hossain MF, Rahman MM, Das BC, Sarker MS, Hossain, MA (2010). Coproscopic and Haematological Approaches to Determine the Prevalence of Helminthiasis and Protozoan Diseases of Red Chittagong Cattle (RCC) Breed in Bangladesh. Pak. Vet. J., 30: 1-6.

Simuunza M, Weir W, Courcier E, Tait A, Shiels B (2011). Epidemiological analysis of tick-borne diseases in Zambia. Vet. Parasitol., 175: 331342.

Talukdar MH, Karim MJ (2001). Subclinical Anaplasma infection in crossbred cattle in Bangladesh. Bangl. Vet. J., 35: 159-160. 